\title{
Are dangerous jobs paid better? European evidence
}

Article

Accepted Version

Georgantzis, N. and Vasileiou, E. (2013) Are dangerous jobs paid better? European evidence. Research in Labor

Economics, 38. pp. 163-192. ISSN 0147-9121 doi:

https://doi.org/10.1108/S0147-9121(2013)0000038005

Available at https://centaur.reading.ac.uk/36015/

It is advisable to refer to the publisher's version if you intend to cite from the work. See Guidance on citing.

Published version at: http://www.emeraldinsight.com/books.htm?issn=0147-

$9121 \&$ volume $=38 \&$ chapterid $=17103070 \&$ show $=$ abstract

To link to this article DOI: http://dx.doi.org/10.1108/S0147-

9121(2013)0000038005

Publisher: Emerald

All outputs in CentAUR are protected by Intellectual Property Rights law, including copyright law. Copyright and IPR is retained by the creators or other copyright holders. Terms and conditions for use of this material are defined in the End User Agreement.

\section{www.reading.ac.uk/centaur}

\section{CentAUR}

Central Archive at the University of Reading 
Reading's research outputs online 


\title{
Are dangerous jobs paid better? European evidence
}

\author{
Nikolaos Georgantzis ${ }^{1}$ \\ University of Granada, GLOBE \& Economics Department; Universitat Jaume I-Laboratorio \\ de Economía Experimental, Spain. email: ngeorgantzis@ugr.es.
}

and

\section{Efi Vasileiou}

University of Panthéon-Assas (Paris-2), France; Universitat Jaume I-Laboratorio de Economía Experimental, Spain. email:vasileiou.efi@gmail.com

\begin{abstract}
This article tests whether workers are indifferent between risky and safe jobs provided that, in labour market equilibrium, wages should serve as a utility equalizing device. Workers' preferences are elicited through a partial measure of overall job satisfaction: satisfaction with job-related risk. Given that selectivity turns out to be important, we use selectivity corrected models. Results show that wage differentials do not exclusively compensate workers for being in dangerous jobs. However, as job characteristics are substitutable in workers' utility, they could feel satisfied, even if they were not fully compensated financially for working in dangerous jobs.
\end{abstract}

JEL classification: $\mathrm{C} 23, \mathrm{~J} 31$

Keywords: Satisfaction with Job Risk; Compensating Wage Differentials; Dangerous Job

\footnotetext{
${ }^{1}$ We acknowledge financial support by the EU (EPICURUS project), the Spanish Ministry of Science and Innovation (ECO2011-23634) and Junta de Andalucía (P07-SEJ-03155). Comments by Dr. Ali Skalli and two anonymous referees of this journal are gratefully acknowledged.
} 


\section{Introduction}

When accepting a given job, a worker implicitly agrees with a whole set of costs and benefits associated to it. In fact, the benefits should, generally speaking, weakly offset the costs, making the worker prefer the job to unemployment and this specific job to other jobs available in the economy. This intuitive idea was formalized in the theory of compensating wage differentials ${ }^{2}$ (CWD), according to which, a worker's wage from a specific job should compensate his effort and other psychological costs and disutilities experienced as a consequence of the whole set of job characteristics.

In this framework, our paper focuses on a specific type of disutility experienced by workers, the likelihood of being physically or mentally injured while undertaking any of the tasks included in the job description (Wei, 1999). The main novelty of this paper is the distinction made between the effect of the wage differential for job riskiness on overall job satisfaction and the effectiveness of the differential to compensate for job riskiness alone.

Job riskiness is a central issue in labour market regulation in all modern countries. However, most of the studies on compensating wage differentials (Sandy and Elliott, 1996; Daniel and Sofer, 1998; Wei, 1999, Arabsheibani and Marin, 2000; Viscusi and Aldy, 2003) explore whether wages compensate workers for working in a dangerous jobs, but not whether this compensation is sufficient to offset the disutility suffered due to the risk. Thus, leaving unanswered questions like: "Do wages behave as a utility-equalizing device in the sense of the theory of compensating differentials?", "Would the premium offered by the market keep the worker in a dangerous work as satisfied as someone in a safer job?" For example, some studies have already found that wage differentials do not compensate for all working conditions (Baudelot and Gollac, 1993; Godechot and Gurgand, 2000). Godechot and

\footnotetext{
2 First proposed by Adam Smith (1776) in the Wealth of Nations, followed by Mincer (1958), Becker (1964) and Rosen (1986).
} 
Gurgand, (2000) measure the effect of various job dis-amenities and efforts on a wage equation in order to test whether workers are sufficiently satisfied with their wage premium accounting for these dis-amenities or efforts. They find that while some bad working conditions may be sufficiently compensated for, it is also true that workers have distinct preferences and expectations for the compensation they should receive for each one of them.

Recent studies have explored the connection between various measures of job dis-amenities and job satisfaction. Clark and Postel-Vinay (2009) explore the effect of employment protection legislation and unemployment insurance benefits on satisfaction with security in Europe. They find that satisfaction with job security is negatively related to such legislation but positively affected by generous unemployment insurance benefits. Furthermore, Böckerman et al. (2011) investigate how firm dynamics affect job satisfaction. They find that wage differentials do compensate for the negative effects of uncertainly in firms that have a high turnover of employees.

Lalive (2007) investigates the determination of individual wages and job satisfaction by using the National Longitudinal Survey of Youth in US. He shows that wage differentials do not compensate for work conditions. Stutzer and Frey (2008) using the German Socio-Economic Panel Study find that commuters report a lower level of subjective well-being, but, other things being equal, they do not get higher wages in response to this. Along this line, our study intends to address the above questions by using risk-related job satisfaction as a partial measure of overall job satisfaction. We assume that satisfaction with job-related risk will not vary with the wage rate if wages compensate exactly for working in risky jobs. Thus, concentrating only on workers' self-reported satisfaction we test the applicability of the theory on compensating differentials to job riskiness. 
Additionally, the examination of whether wage differentials act as a utility equalizing device on job risk makes it possible to correct for several potential biases related to the empirical estimations. In particular, we investigate the problem of sample selection. This may arise if the decision to work in a dangerous job is not random. For example, some workers may choose jobs with bad working conditions precisely because of the compensating differentials, while others may simply be less adverse to these kinds of jobs because of a different attitude towards risk.

This study is organized as follows: Section 2 begins by describing the framework of compensating differentials adapted to the issue of job risk. At the same time, the empirical biases usually found in the relevant literature are exposed. Section 3 presents the relationship between satisfaction and the theory of compensating differentials. Section 4 develops the test of compensating differentials for dangerous jobs. Section 5 gives background on the dataset and some preliminary evidence. Section 6 reports the results and Section 7 concludes.

\section{The theory of compensating differentials and job risk}

The theory of compensating differentials tries to explain wage disparities in the labour market assuming that the employees have different preferences for different job attributes and that jobs are different too. The key implication of the theory is that, as long as all persons in the population agree on whether a particular job characteristic is "good" or "bad", those working under good conditions would be paid less (making workers "buy" the enjoyable environment) and those working under bad conditions would be paid more (Rosen, 1986). The theory is immediately applicable to the case of wage compensations for bearing the risk of injury or even death ${ }^{3}$. Most workers can be expected to value both higher wages and

\footnotetext{
3 An important strand of empirical studies have investigated the relationship between a wage premium and undesirable working conditions other than risky jobs (for a review, see Rosen 1986). Bad working conditions usually refer to dangerous and stressful conditions at the workplace (Duncan and Holmlund, 1983; French and
} 
greater levels of safety, but some are presumed to be willing to accept some additional risk in exchange for a higher wage yielding the same overall level of utility. Thus, firms accounting for worker heterogeneity regarding the appropriate wage-safety tradeoff, may choose to invest in costly procedures, rather than economizing on safety and redistributing the savings among workers in the form of higher wages. This has important implications both for firm strategies and public policy towards risky jobs.

Many empirical studies report a positive relationship between wages and unsafe working conditions. A survey of some earlier studies, together with an investigation into the variety of results, can be found in Marin and Psacharopoulos (1982). More recent surveys can be found in Meng and Smith (1990); Martinello and Meng (1992); Sandy and Elliott (1996); Daniel and Sofer (1998); Wei (1999); Arabsheibani and Marin (2000); Viscusi and Aldy (2003). In general, the evidence is ambiguous. Some studies find that, while fatal risk has a positive and significant effect on wages, non-fatal risk tends to have negative and insignificant effects on wages (Arabsheibani and Marin, 2000). Some studies find that both variables have positive and significant effects (Garen 1988). However, when some other factors are taken into account (such as union status or industry-level variables) the apparent ubiquity of the positive relationship between job risk and wages breaks down (Sandy and Elliott, 1996; Dorman and Hagstrom, 1998; Daniel and Sofer, 1998). Yet, the positive and statistically significant wage premium for fatal job risks provides the most robust empirical support for the theory of compensating differentials (Viscusi and Aldy, 2003). Some authors have recognized that the divergent results found in the literature on compensating differentials are due to the existence of several biases.

Dunlap, 1998), inconvenient location and commuting time (Stutzer and Frey, 2008), shift work and flexible working hours (Kostiuk, 1990; Gariety and Shaffer, 2001; Lanfranchi et al, 2002) and perception of job instability measured by product market volatility (Morreti, 2000; Magnani, 2002). 
An omitted-variable bias due to the correlation between unobserved worker productivity (such as talent, innate ability) and job risk has been indicated by some authors (Brown, 1980; Duncan and Holmlund, 1983; Hwang, Reed and Hubbard, 1992). For instance, more able workers are likely to earn higher wages, and these workers will probably "spend" some of their additional income on job amenities. Thus, more able workers will have higher wages and higher levels of the desired job amenities. Additionally, a major concern in the literature on compensating differentials is the issue of self-selection (Lee, 1978; Kostiuk, 1990; Lanfranchi et al, 2002; Purse, 2004). One reason is that, when fatality or injury risk is a normal good, employees with high earnings potential (e.g. better educated workers) will select themselves into safer jobs (Viscusi, 1978).

There are also several empirical studies that do not support the hypothesis of compensating wage differentials attributing the failure to market frictions and imperfect information (Dickens and Katz, 1987; Krueger and Summer, 1988; Brown and Medoff, 1989; Kruse, 1992; Gronberg and Reed; 1994; Dorman and Hagstrom, 1998; Sandy and Elliott, 1996; Daniel and Sofer, 1998; Arabsheibani and Marin, 2000; Bender and Mridha, 2011). More specifically, labour market segmentation and dualism theory predict a positive relationship between wages and good working conditions. The theory of labour market segmentation (see e.g., Doeringer and Piore, 1971; Cahuc and Zajdela, 1991) initially distinguishes between two segments, one characterized by better, permanent, well-paid jobs with career prospects (the 'primary segment'), and the other having temporary, poorly paid jobs without any career prospects (the 'secondary segment'). In a recent study Bender and Mridha (2011) show that the standard CWD theory does not necessarily hold because labour market forces may fail to induce firms to pay a CWD. 
The literature also addresses problems with measuring risk compensation. The job risk has been measured in a number of ways and it relies, with few exceptions, upon risk measures which are available by industrial or occupational category (Thaler and Rosen, 1975; Brown, 1980; Arnould and Nichols, 1983; Garen, 1988; Dorman and Hagstrom, 1998). Few studies (Hamermesh, 1978; Viscusi, 1978, 1979; Biddle and Zarkin 1988; Fairris, 1989; Gegax et al, 1991; Böckerman and Ilmakunnas, 2006) have been based on workers' perception of their job risk. A possible explanation for the scarcity of subjective assessment studies on job riskiness is that most of the available datasets ${ }^{4}$ do not include information on the worker's perceived job attributes.

In addition to the scarcity of the datasets which include the perceived individual risk, many researchers are reluctant to use subjective assessments of risk because part of the literature on psychology and economics has documented biases in individual assessments. The literature on risk perception found that individuals respond differently to risks depending on whether they are seen as violations of personal autonomy (Starr, 1969; Dorman, 1996). As a result, they feel a lower aversion to risks they take for themselves than to risks that they regard as being imposed on them by others. A second problem is that people tend to overestimate low probability events and to underestimate high probability ones (Kahneman and Trevsky, 1979). This should also apply to job choice. For the overwhelming majority of jobs, the risk of a fatal accident is very low. From the evidence on how people make other types of decisions, it seems likely that most people ignore the probability of a fatal injury when choosing a job. Hence, if many people do not pay attention to such risks, employers have limited incentives to pay compensating differences. Thus, measured differences may not

\footnotetext{
4 To the knowledge of the authors, the University of Michigan's Survey of Working Conditions (SWC), the Quality Employment Survey (QES) and the EPICURUS dataset are the only datasets including a subjective risk variable obtained from workers' perception of their jobs' dangerous and unhealthy conditions. However, the other two studies are cross section data obtained from American respondents. Thus, the dataset analyzed here is the only one with a panel structure including a question on perceived job risk by European workers.
} 
reflect workers' willingness to accept a compensation for taking those risks but, rather, employers' costs of providing the corresponding safety measures (Dickens, 1985). However, this suggests that many workers do not know how dangerous a job is when they take it, and learn over time. Thus, one can assume that individual perceptions when workers already have the job provide an accurate measure of job risk. Lastly, it is found that survey respondents overreact to newly identified risks. The original argument was advanced by Slovic in the 1970s (see Lichtenstein and Slovic, 1971). However, as stated by Viscusi and O'Conner (1984), these effects may not be as great in job safety contexts, probably because workers' familiarity with job risks make them less alarmed by information regarding a minor increase in risk.

This study assumes that self-reported information on job risk is a broad concept covering much more than the occupational accidents officially recognized by national insurance systems ${ }^{5}$. The way in which workers perceive their job dangerousness will be useful for an outsider evaluating job risk, and it probably affects economic outcomes. While it is unlikely to perceive the job risk as revealed in the labour market, a worker feeling that there is a high probability of being killed or suffering physical injury may be less motivated and may even leave the job voluntarily (Viscusi 1979). Furthermore, depending on a job's dangerousness, a worker will be more or less likely to invest in firm-specific human capital that will increase his/her commitment to the employer. Therefore, this subjective indicator could be a substantial value for labour market analysis for firm strategies and economic policy towards risky jobs.

\footnotetext{
${ }^{5}$ As argued by Viscusi (1993), the ideal risk measure would reflect subjective assessment of the risk of a job by both the workers and the firm, but in practice we have a less perfect measure. The only exception known which used linked firm-worker data is the paper by Dale-Olsen (2005) and Lalive et al (2006).
} 


\section{Satisfaction and compensating wage differentials for job risk}

This section introduces some approaches used in the literature for testing the theory of compensating differentials that do not only rely on the hedonic wage methodology, but also on stated job satisfaction used as a subjective proxy of utility at work (Godechot and Gurgand, 2000; Clark, 2003; Stutzer and Frey, 2008; Lalive, 2007; Böckerman and IImakunnas, 2006, Helliwell and Huang, 2010; and Böckerman et al, 2011).

To illustrate this framework, consider the linear specification:

$$
\begin{aligned}
& U=a+\beta X+\delta D+\gamma w \\
& w=\phi+\mu D+\pi K
\end{aligned}
$$

where $U$ is job satisfaction, $X$ and $K$ are vectors of exogenous variables. We denote by $D$ the probability of injury on the job and define $w$ as the worker's wage rate (or its natural logarithm), whereas $\alpha$ and $\phi$ are constants.

A compensating wage differential would imply that $\mu=-\delta / \gamma \cdot{ }^{6}$ Applying this in the wage equation (2) and then inserting the wage equation into the utility function (1) we get:

$$
U=a+\beta X+\pi \gamma K+\gamma \phi
$$

In this setting, the existing literature proposes two ways of testing for compensating wage differentials when using job satisfaction as a proxy for utility.

Changing notations as: $\alpha^{\prime}=\alpha+\gamma \phi, \beta^{\prime}=\beta, \pi^{\prime}=\gamma \pi$, one empirical strategy is to check whether $\delta^{\prime}=0$ holds in the job satisfaction equation

\footnotetext{
${ }^{6}$ Note that $\mu>0$ or $\mu<0$ are sufficient conditions to reject the theory
} 


$$
U=a^{\prime}+\beta^{\prime} X+\pi^{\prime} K+\delta^{\prime} D
$$

where wage is not included, assuming that satisfaction is independent of the working conditions. This empirical strategy is employed by Godechot and Gurgand (2000), Clark (2003), Böckerman and IImakunnas, (2006) and Stutzer and Frey (2008).

Alternatively, compensating wage differentials can be tested by checking whether $\gamma^{\prime}=0$ in the job satisfaction equation

$$
U=a^{\prime}+\beta X+\pi^{\prime} K+\gamma^{\prime} w
$$

where dis-amenities are not included and which would imply that the wage differential offered by the market would be just enough to keep the worker on the same indifference curve. This test is applied by Lalive (2007).

Consistently with the above models, this study examines whether wages act as a utility equalizing device by assuming that satisfaction will not vary with the wage rate if wages compensate exactly for the bad working conditions. However, the main econometric issue is that the coefficient $\gamma$ from the estimated model (equation 5) should be unbiased. However, this may not be the case if some workers choose jobs with bad working conditions because of the compensating differentials while others prefer these jobs because they have different attitudes towards risk. Thus, the issue of self-selection is crucial to the analysis. This study attempts to provide unbiased estimates for $\gamma$. It thus relies on an endogenous switching regression model (Maddala, 1983). 


\section{A test of compensating wage differentials for risky jobs using endogenous switching regression models}

Some workers may choose dangerous jobs because of the compensating differentials while others, with a lower aversion to danger prefer riskier jobs and therefore make wage premiums unnecessary. Thus, the estimate of the necessary compensating differential will be biased downwards. Additionally, in the framework of the endogenous switching regression model, wages are allowed to be different across the two groups. Wages in dangerous jobs may be identified by different characteristics from those in safe jobs, so that the data should not be pooled. Suppose that employers give a wage premium to employees with individual characteristics such as education or experience in order to reduce the accidents in the jobs. Thus, two different regimes are distinguished, one for those working in a dangerous job and one for those working in a safe job.

The switching regression model estimates the following system describing log wages for dangerous $\left(w_{d}\right)$ and $\left(w_{s}\right)$ for safe jobs.

$$
\begin{array}{lll}
\text { Situation 1: } & w_{d}=\beta_{d} X+u_{d} & \text { for } C=1 \\
\text { Situation 2: } & w_{s}=\beta_{s} X+u_{s} & \text { for } C=0
\end{array}
$$

and one "selection" equation which determines which sector is chosen by the individuals, where $C$ is the dangerous job choice.
Dangerous Job Choice:
$C=\tau_{3} Z+v_{3}$
(7) [reduced form $]$ 
In the wage equations (6), $w_{d}$ and $w_{s}$ are the log hourly wages ${ }^{7}$ of workers in dangerous and safe jobs, respectively, $X$ is a vector of exogenous variables, while $u_{d}, u_{s}$ are unobserved random errors. In equation (7), $C$ is a binary variable for a dangerous job, taking the value 1 when the job is dangerous and zero otherwise, $\mathrm{Z}$ is a vector of variables influencing the choice of a dangerous job and $v$ is an error term. Note that, in the reduced form (7), Z must contain all the $X$ variables. Among the extra variables, there should be at least one which permits model identification. This variable is the instrument. This variable must affect wage only via its effect on the choice of a worker being in a dangerous job. In our model, the income of other household members is used as an instrument ${ }^{8}$.

Equation (7) is estimated using a Probit model capturing sample selection. Inverse Mill ratios $\vartheta(\mathrm{Z} \widehat{\delta}) / \Phi\left(\mathrm{Z}_{i} \widehat{\delta}\right)$ are obtained, where $\vartheta($.$) and \Phi($.$) are, respectively, the probability density$ and cumulative functions of the standard normal distribution, which are then used to correct for selectivity bias and obtain unbiased estimates of the wages (6) by estimating:

$$
\begin{aligned}
& w_{d}=\beta_{d} X+\sigma_{d} \vartheta(\mathrm{Z} \widehat{\delta}) / \Phi\left(\mathrm{Z}_{i} \widehat{\delta}\right) \\
& w_{s}=\beta_{s} X-\sigma_{s} \vartheta(\mathrm{Z} \widehat{\delta}) / 1-\Phi\left(\mathrm{Z}_{i} \widehat{\delta}\right)
\end{aligned}
$$

assuming that the covariances $\sigma_{d}, \sigma_{s}$ between the reduced-form equation (7) and the wage equations errors are non zero. Estimates of $\sigma_{d}, \sigma_{s}$ indicate the nature of self-selection into each sector. Positive selection into each sector implies a positive $\sigma_{d}$ and a negative $\sigma_{s}$. In an

\footnotetext{
7 These are wage averages obtained by dividing the total regular monthly income from the main employment by the total amount of hours worked usually, excluding overtime.

8 The appropriateness of the chosen instrument is discussed in detail in section 6.
} 
economic context, positive selection means that workers select themselves into each one of the two sectors because of preferences or comparative advantages. Negative selection into a dangerous job implies that workers prefer to avoid dangerous jobs, but they seem to have chosen them because of the risk premium or because they could not find other jobs.

Note that, following Maddala (1983), one can rewrite equations (8) as:

$$
E(w)=\beta_{s} X+\left(\beta_{d}-\beta_{s}\right) X \Phi\left(\mathrm{Z}_{i} \widehat{\delta}\right)+\left(\sigma_{d}-\sigma_{s}\right) \vartheta\left(\mathrm{Z}_{i} \widehat{\delta}\right)
$$

Assuming that both categories have identical coefficients $\left(\beta_{d}=\beta_{s}\right.$ and $\left.\gamma_{d}=\gamma_{s}\right)$ for all $X$ except for the constants, we rewrite equation (9), as follows, which is known as treatment effect model:

$$
E(w)=\beta X+\alpha \Phi\left(\mathrm{Z}_{i} \widehat{\delta}\right)+\left(\sigma_{d}-\sigma_{s}\right) \vartheta\left(\mathrm{Z}_{i} \widehat{\delta}\right)
$$

where $\alpha$ is equal to the difference in wages and captures the effect of a dangerous work on the wage.

Finally, equation (11) describes satisfaction with job-related risk, which is chosen instead of overall job satisfaction due to the exanimation of only one characteristic of the job: its dangerousness. Therefore, it is examined whether workers are sufficiently satisfied with their monetary compensation for this specific dis-amenity. As Adam Smith stated, jobs differ in many characteristics, all of which can give rise to compensating differentials. In this study, it is supposed that jobs differ in only one characteristic: the dangerousness of the job. The choice of this specific part of job satisfaction is very important in our framework as one could feel reasonably satisfied with the dangerousness of his/her job, but dissatisfied with many other aspects such as working times, security, type of job, etc. This is particularly true in the sense that a worker's wage might include compensation for job dangerousness but also for a variety of other dis-amenities. To ensure that this strategy correctly identifies the effect under 
study, employer characteristics that are controlled for in the model partly capture the role of the remaining job characteristics in wage determination.

$$
S=\not X+\lambda\left(w_{d}-w_{s}\right)+\varepsilon \text { for } \mathrm{C}=1 / 0
$$

In equation (11), the satisfaction variable, $S$, is a latent one. The appropriate model is the ordered Probit model. In an ordered Probit model, the latent probability of reporting a job satisfaction level $S^{*}$ is:

$$
S=\Phi^{-1}\left(S^{*}\right)=\gamma X+\lambda\left(w_{d}-w_{s}\right)+\varepsilon \quad \varepsilon \mid X \sim \operatorname{Normal}(0,1)
$$

where $X$ is a vector of exogenous personal and work-related characteristics, $\gamma$ is a vector of coefficients to be estimated, and $\varepsilon$ indicates the error term. Assuming that $\mu_{1}<\mu_{2}<\ldots<\mu_{j}$ where $\mu_{1}, \ldots \mu_{j}$ are the cutoff points for the latent variable,

$$
S^{*}=\left\{\begin{array}{l}
0, \text { if } S^{*} \leq \mu_{1} \\
1, \text { if } \mu_{1} \leq S^{*} \leq \mu_{2} \\
\cdots \\
\text { j, if } S^{*}>\mu_{j}
\end{array}\right.
$$

the parameters $\gamma$ and $\mu$ can be estimated by maximum likelihood.

The empirical strategy here is to check whether $\lambda=0,{ }^{9}$ which would imply that the wage differential offered by the market would be just enough to keep the worker on the same indifference curve. Thus, if wage differentials only reflect compensation for risky jobs, workers will not prefer jobs with high wages to jobs with low wages ${ }^{10}$. The alternative

\footnotetext{
${ }^{9}$ One may argue that this empirical model focuses only on injury risk. But in reality the wage is (potentially) affected by many different compensating differentials. If these are correlated with injury risk, it would bias the results that are being generated here. However one should consider (i) which attributes should be included and which ones should not, (ii) the potentially relevant attributes are not necessarily observable and (iii), even if they were, the resulting model would be a very complex one.

${ }^{10}$ The differential $w_{d}-w_{s}$ is the predicted value difference of wages for dangerous and safe jobs for each worker.
} 
hypothesis of non-competitive determination of the wage structure $\lambda>0$ or $\lambda<0$ would indicate dualism of the labour market. If this alternative view of the labour market dominates the competitive view, one may find that wage increases/decreases will be reflected on higher/lower reported satisfaction levels (Clark, 2003).

\section{Job risk, satisfaction and wages: First empirical evidence from a European survey}

Our analysis uses the EPICURUS dataset ${ }^{11}$. The survey includes general questions, aimed at identifying the respondent's individual characteristics. Questions concerning age, gender, marital status, employment status, education, occupation and socio-economic and labour market status characteristics, are included. The respondent is also asked several questions related to income, and about aspects related to job satisfaction, as well as satisfaction with several features of work.

In this study, a sub-sample of 3,030 workers from France, Greece, the UK and the Netherlands is used. The sample includes workers occupied in paid employment between 18 to 65 years of age. Self-employed, retired, and unemployed persons, as well as housewives and students are excluded in order to keep the sample homogeneous. Moreover, those whose highest qualification is third level education are excluded from the main questionnaire because the designers of this questionnaire decided to excluded individuals with an education level 5 or 6 (ISCED International Classification 1997) in order to keep the sample as homogeneous as possible. All workers were interviewed on line with the exception of Greece where face-to-face interviews were conducted. The agency that ran the surveys for Greece,

\footnotetext{
11 This survey was elaborated in 2004 by the EPICURUS team in the framework of a European project under the Fifth Framework Programme "Improving Human Potential" (contract number: HPSE-CT-2002-00143). The variables included in our model are defined in the Appendix Table 6.
} 
France, United Kingdom and the Netherlands suggested that it was not necessary or useful to apply weighing techniques on the data. All the employee groups were sufficiently represented. The fieldwork in UK, which was done online, had a gross sampling based on age, gender and education level. In the screening phase 654 persons were screened out; and 1002 respondents completed the interview. For Greece, in the screenings phase, 500 respondents were screened out because they did not belong to the target population; and 800 respondents received a complete interview. In the Netherlands in the screening phase 413 persons were screened out; and 1007 respondents completed the questionnaire.

We distinguish between workers who work in dangerous jobs and those who work in safe jobs based on the following question:

Question: "Would you say that your job is dangerous (risk of physical accidents, contact with dangerous products)?"

Response: "Frequently, sometimes, hardly ever"

If a worker replies that his/her job is dangerous: either frequently or sometimes, it indicates that he/she is working in a dangerous job. Alternatively, if a worker replies that his/her job is hardly ever dangerous, the worker is categorized as belonging to the safe job group.

The level of "satisfaction with job-related risk" is derived from the following question:

"How satisfied are you with your job's physical risk?"

The answers are ranked on a 1 (completely dissatisfied) to 10 (completely satisfied) scale. 


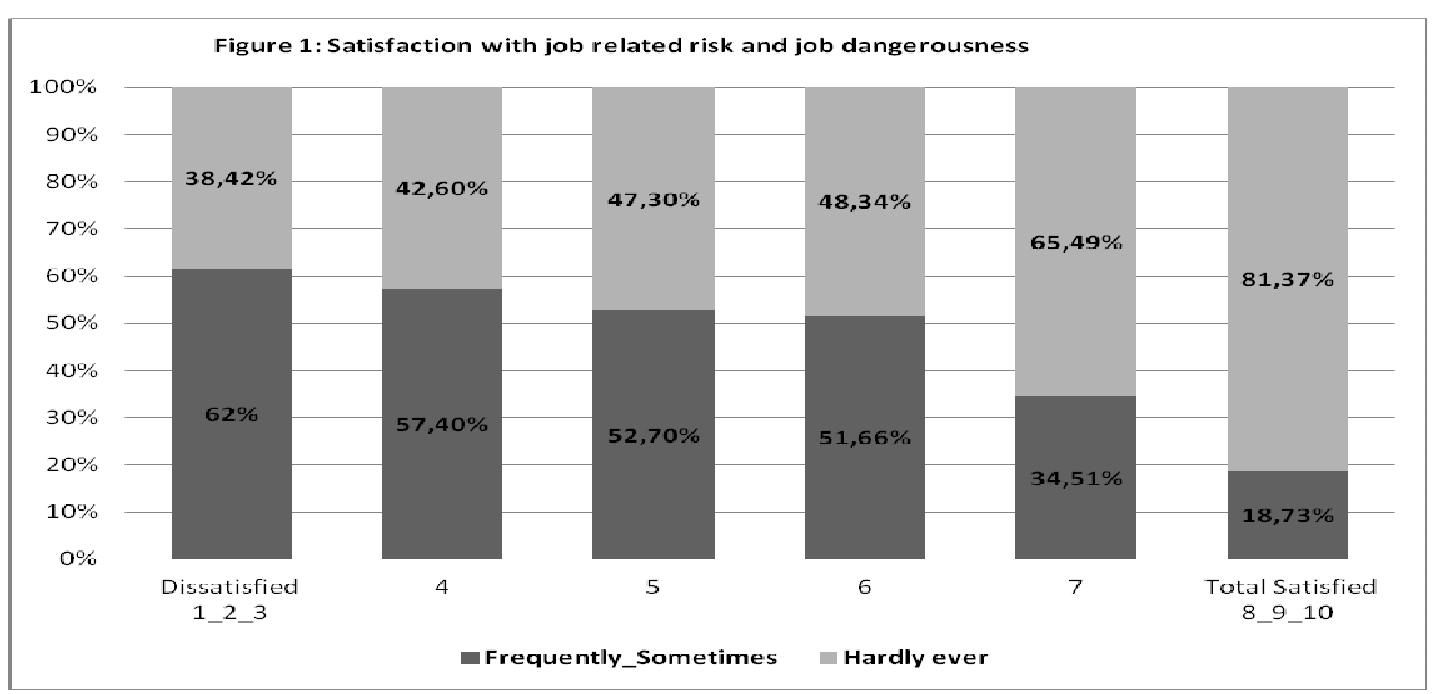

Figure 1 provides a first approach to the negative relation between risk at job and an individual's satisfaction with dangerousness at work. It is found, on average that the workers who are most satisfied with job-related risk are in safe jobs and this difference is large (81,37\%). Approximately only $18,63 \%$ of satisfied workers viewed their job as being dangerous. For those who are dissatisfied with their job risk, $61,58 \%$ of workers believe their job is dangerous. Thus, the fear of a job accident is confined to workers with low satisfaction in this domain. However, the raw correlation between job risk and satisfaction does not account for wages and the fact that we are comparing people with heterogeneous preferences facing different restrictions. Thus, the observed lower satisfaction of people who work in dangerous jobs might just reflect that these are people with different socio-demographic and socio-economic characteristics.

Table 5 in the Appendix presents sample statistics for workers occupied in dangerous and safe jobs, on the basis of their perception of job risk. Each of these variables affects wages and, at the same time, determines a worker's choice of a dangerous job. There is also substantial literature suggesting that women are more risk averse than men and those married with children are more risk averse than those without (DeLeire and Levy, 2004; Dohmen et al, 2005; Sloane and Grazier, 2006). Thus, workers with a strong aversion to risk will tend to 
make occupational choices which sort them into safer jobs. Hence there are strong empirical results showing that workers sort into jobs on the basis of their preferences. Thus, it is difficult to separate compensating differentials from returns to skill where the employee is being rewarded for his ability to manage the risk inherent in a particular job. This skill might result from prior training or experience which enables some workers to be more productive in a dangerous job, but such characteristics may not be relevant to a safe job. For example, the fact that men are more likely to work in a dangerous job, makes it possible that the "gender earnings gap" often found in empirical studies may be partly a compensation for job riskiness (Nielsen, 2005). Similarly, unionized workers are more likely to work in dangerous jobs than non-union workers. Previous empirical work has shown that unions raise the risk premium because they provide members with both more information about occupational risk and a mechanism for voicing their concerns about risk, something which is not available to nonunion workers (Thaler and Rosen, 1975). So it is possible that some of the union wage differential found in wage studies is actually a compensation for dangerous jobs. As stated before, one needs to account for possible biases arising from worker selection into risky or non-risky jobs when evaluating the compensating differentials hypothesis.

\section{Econometric results}

Table 2 reports, the selectivity-corrected wage equations for workers in dangerous and safe jobs $^{12}$. An important ingredient in the selectivity-corrected models is the instrument which permits model identification. In our model, this variable must affect wage only via its effect on the choice of a worker to be in a dangerous job. It has been argued that social background characteristics do not impact on the wage but on the job decision. To our knowledge only Daniel and Sofer (1998) have used two instruments for the choice of a risky job (the number

12 For comparison, Table 7 in the Appendix contains OLS estimates of wages including "job risk" as a dummy variable. 
of children and the log of the spouse's income). They found that both have significant effect on the choice of risky jobs. Accordingly, in this study, whether another household member has income ${ }^{13}$ (inco_household) is used as an instrument for the choice of being in a risky job $^{14}$.

Following Coles et al (2007), one can suggest that job choice may be dependent on productivity-irrelevant characteristics. The identifying restriction chosen in our study, namely, the household member's income conforms to the above intuition. In the market equilibrium envisaged here, there is a population of workers with different social background characteristics (Daniel and Sofer, 1998). In this case, workers who have a comparative advantage in taking safe jobs -that is, those who can be selective because of their extra household member's income - take employment in safe jobs and, in equilibrium, earn a lower average wage. Conversely, those who do not have the extra household member's income take more dangerous jobs and enjoy the corresponding wage premium. Additionally, in order to provide further evidence on the appropriateness of the chosen instrument the Staiger and Stock (1997) test for exogeneity is used. Staiger and Stock (1997) argue that, if the F-statistic value associated with the chosen instruments in the first stage regression is above 10 , then the quality of the instrument is acceptable. In this model the F-stat value is 11.1 indicating that the chosen instrument is adequate.

\section{Reduced form Probit equation}

We start by presenting the results of the first step of the analysis, the reduced form choice equation (7) for the EU sample (Table 1, column 1). The estimation of the choice equation

\footnotetext{
13 The household income includes labour and capital income of other household members.

14 The variable "number of children" is not significant in the Probit equation.
} 
makes use of the Probit method to identify the factors that influence the decision of individuals to work in dangerous jobs. As expected, the household member's income, the variable that affects only the choice process, is highly significant. Those individuals whose family members provide the household with extra income are less likely to work in dangerous jobs, as compared to those who do not have an additional income from their family.

The results also confirm the picture which already emerges from the raw data (Table 5 in the Appendix): the probability of choosing a dangerous job is higher if the worker is male, married or having a partner. Educated workers are less likely to be in dangerous jobs. The probability of ending up in a dangerous job is an inverse U-shaped function of tenure with a maximum reached at around 13 years in the same job. This finding suggests that younger workers may be more willing to accept dangerous jobs since they are in the beginning of their careers and the possibility of finding a safer job is lower or it might simply be an age-related shift in preferences.

Union membership affects positively the choice process. However, this result should be interpreted with caution. Many authors emphasize that there is a possible endogenous relationship between union status and the choice of a dangerous job (Biddle and Zarkin, 1988). It could be the case that workers in dangerous jobs are more likely to be unionised in order to facilitate communication with the hierarchy or co-workers.

Country-specific effects show that workers in Greece are more willing to accept dangerous jobs, followed by French and to a lower extent by British workers. This may signal the importance of having a "job" even if it is dangerous in countries such as Greece or France with relatively high unemployment rates. 
The above results confirm the idea that people do not choose jobs at random. It seems that this is particularly important when comparing what influences the choice of occupation among different groups of workers, as specific groups may have particular preferences. Thus, previous estimates of wage premium for dangerous jobs are misleading since they may confound equalizing wage effects with inter-personal differences. As stated before, one needs to account for any biases arising from worker selection into risky or non-risky jobs when evaluating the compensating differentials hypothesis. 
TABLE 1 Dangerous choice, Probit model, marginal effects

\begin{tabular}{lcl}
\hline & Reduced form & \\
\hline Variables & Marginal effects & Z-value \\
\hline Co_married & 0.080 & $3.43^{* * *}$ \\
Male & 0.130 & $6.54^{* * *}$ \\
Tenure & 0.010 & $2.70^{* * *}$ \\
Tenure $/ 100$ & -0.039 & $3.32^{* * *}$ \\
Secondary education & -0.093 & $3.73^{* * *}$ \\
Upper secondary education & -0.058 & $2.21^{* * *}$ \\
Children & -0.008 & 0.40 \\
Trade Unio Mb & 0.121 & $4.75^{* * *}$ \\
Manager & 0.058 & $1.74^{*}$ \\
Clerk & -0.159 & $5.92^{* * *}$ \\
Craft_skilled & 0.303 & $7.70^{* * *}$ \\
Other occupant. & 0.133 & $4.41^{* * *}$ \\
Private & -0.038 & $1.68^{*}$ \\
Unempl.Exp & 0.053 & 1.51 \\
Firm size $<99$ & 0.092 & $3.35^{* * *}$ \\
Firm size $<500$ & 0.017 & 0.70 \\
Sector-Service & -0.038 & 1.23 \\
Sector -other & -0.068 & $1.96^{* *}$ \\
Greece & 0.350 & $10.98^{* * *}$ \\
France & 0.239 & $8.03^{* * *}$ \\
UK & 0.116 & $3.91^{* * *}$ \\
Household member's income & -0.041 & $1.92^{* *}$ \\
\hline Log likelihood & -1624.76 & \\
Pseudo R ${ }^{2}$ & 0.18 & \\
Observations & 3,030 & \\
\hline Note*, **** indicate significance at $10 \%, 5 \%, 1 \%$ & \\
\hline
\end{tabular}


TABLE 2 Selectivity-corrected wage equations models

\begin{tabular}{|c|c|c|c|c|c|c|}
\hline \multicolumn{5}{|c|}{ Switching regression model } & \multicolumn{2}{|c|}{$\begin{array}{l}\text { Treatment effect } \\
\text { model }\end{array}$} \\
\hline & \multicolumn{2}{|c|}{1} & \multicolumn{2}{|c|}{2} & \multicolumn{2}{|c|}{3} \\
\hline & \multicolumn{2}{|c|}{ Dangerous choice } & \multicolumn{2}{|c|}{ Safe choice } & \multicolumn{2}{|c|}{ All workers } \\
\hline & coef & $t$-stat & coef & $t$-stat & coef & $t$-stat \\
\hline Co_married & 0.080 & $2.07 * *$ & 0.013 & 0.47 & 0.034 & 1.60 \\
\hline Male & 0.212 & $3.19 * * *$ & 0.028 & 0.68 & 0.094 & $2.55 * *$ \\
\hline Tenure & 0.022 & $3.17 * * *$ & 0.015 & $3.07 * * *$ & 0.017 & $4.56^{* * *}$ \\
\hline Tenure $^{2} / 100$ & -0.053 & $2.18 * *$ & -0.014 & 0.87 & -0.027 & $2.08 * * *$ \\
\hline Sec. educated & -0.017 & 0.35 & 0.165 & $4.00 * * *$ & 0.101 & $3.38 * * *$ \\
\hline Up_se educated & 0.077 & $1.72 *$ & 0.181 & $4.77 * * *$ & 0.143 & $5.40 * * *$ \\
\hline Trade Unio Mb & 0.121 & $2.17 * *$ & -0.064 & 1.51 & -0.002 & 0.08 \\
\hline Manager & 0.201 & $3.59 * * *$ & 0.211 & $4.74 * * *$ & 0.203 & $6.30 * * *$ \\
\hline Clerk & 0.017 & 0.18 & 0.215 & $4.59 * * *$ & 0.134 & $3.01 * * *$ \\
\hline Craft_skilled & 0.184 & 1.58 & -0.293 & $2.84 * * *$ & -0.133 & $1.71 *$ \\
\hline Other occupant. & 0.162 & $2.34 * *$ & -0.015 & 0.31 & 0.044 & 1.07 \\
\hline Private & -0.172 & $4.54 * * *$ & 0.022 & 0.79 & -0.041 & $2.02 * *$ \\
\hline Unempl.Exp & -0.076 & 1.42 & -0.069 & 1.59 & -0.074 & $2.49 * *$ \\
\hline Firm size $<99$ & 0.048 & 0.93 & -0.037 & 0.97 & -0.010 & 0.33 \\
\hline Firm size $<500$ & 0.002 & 0.06 & 0.053 & $1.81 *$ & 0.036 & $1.78 *$ \\
\hline Service_sector & -0.102 & $2.31 * *$ & 0.006 & 0.15 & -0.029 & 1.09 \\
\hline Other service & -0.089 & 1.53 & 0.025 & 0.49 & -0.012 & 0.37 \\
\hline Greece & -0.749 & $5.57 * * *$ & -1.242 & $13.27 * * *$ & -1.073 & $13.36^{* * *}$ \\
\hline France & -0.025 & 0.25 & -0.341 & $5.47 * * *$ & -0.228 & $4.10 * * *$ \\
\hline UK & -0.409 & $6.49 * * *$ & -0.492 & $12.02 * * *$ & -0.458 & $14.12 * * *$ \\
\hline $\begin{array}{l}\text { Worker being in } \\
\text { dangerous job }\end{array}$ & - & - & - & - & -0.073 & $1.82 *$ \\
\hline Selection term & 0.329 & 1.44 & -0.540 & $2.93 * * *$ & -0.458 & $3.22 * * *$ \\
\hline Constant & 1.49 & $4.06 * * *$ & 1.689 & $19.28 * * *$ & 1.96 & $26.00 * * *$ \\
\hline Adjusted $\mathrm{R}^{2}$ & \multicolumn{2}{|c|}{0.50} & \multicolumn{2}{|c|}{0.47} & \multicolumn{2}{|c|}{0.49} \\
\hline Observations & \multicolumn{2}{|c|}{1,096} & \multicolumn{2}{|c|}{1,934} & \multicolumn{2}{|c|}{3,030} \\
\hline
\end{tabular}

Note*, ${ }^{* *}, * * *$ indicate significance at $10 \%, 5 \%, 1 \%$ levels, respectively. 
TABLE 3 Satisfaction with risk equation (ordered Probit)

\begin{tabular}{|c|c|c|c|c|}
\hline & 1 & & 2 & \\
\hline Variables & Coef & $t$-values & Coef & $t$-values \\
\hline Male & -0.011 & 0.27 & - & - \\
\hline Tenure & -0.008 & 1.22 & - & - \\
\hline Tenure $^{2} / 100$ & 0.031 & 1.52 & - & - \\
\hline Second educated & 0.055 & 1.09 & 0.025 & 0.67 \\
\hline Upper second educated & 0.189 & $3.57 * * *$ & 0.147 & $2.85 * * *$ \\
\hline Unemployment experience & -0.224 & $3.11 * * *$ & -0.190 & $2.81 * * *$ \\
\hline Trade Union membership & -0.191 & $3.97 * * *$ & - & - \\
\hline Sector: service & -0.168 & $2.76 * * *$ & -0.203 & $-2.16 * *$ \\
\hline Sector: other & -0.092 & 1.23 & -0.126 & 0.70 \\
\hline Managers & 0.204 & $3.00 * * *$ & 0.175 & $2.88 * * *$ \\
\hline Clerks & 0.235 & $3.85 * * *$ & 0.196 & $3.08 * * *$ \\
\hline Crafts \& Skilled workers & -0.136 & $1.70 *$ & -0.027 & 0.22 \\
\hline Other occupations & 0.078 & 1.29 & 0.092 & 1.62 \\
\hline \multicolumn{5}{|l|}{ Interaction Terms } \\
\hline Wage differentials*UK & -0.704 & $6.26 * * *$ & -0.689 & $6.21 * * *$ \\
\hline Wage differentials*France & -0.125 & 0.77 & -0.071 & 0.79 \\
\hline Wage differentials*Greece & -0.548 & $5.36 * * *$ & -0.252 & $1.75^{*}$ \\
\hline Wage differentials*male & - & - & -0.470 & $4.13 * * *$ \\
\hline Wage differentials*tenure & - & - & -0.017 & 1.18 \\
\hline Wage differentials $*$ Tenure $^{2}$ & - & - & 0.006 & 1.33 \\
\hline Wage differentials*Trd.Un. & - & - & -0.100 & 1.12 \\
\hline Adjusted $\mathrm{R}^{2}$ & \multirow{2}{*}{\multicolumn{2}{|c|}{$\begin{array}{c}0.08 \\
3,030\end{array}$}} & 0.09 & \\
\hline Observations & & & & \\
\hline
\end{tabular}

TABLE 4 Overall job satisfaction (ordered Probit)

\begin{tabular}{|c|c|c|}
\hline Variables & Coef & t-values \\
\hline Male & -0.128 & $2.93 * * *$ \\
\hline Tenure & -0.005 & 0.85 \\
\hline Tenure $^{2} / 100$ & 0.033 & $1.68^{*}$ \\
\hline Secondary education & -0.012 & 0.25 \\
\hline Upper secondary education & -0.067 & 1.28 \\
\hline Unemployment experience & -0.109 & 1.59 \\
\hline Trade Union membership & -0.126 & $2.72 * * *$ \\
\hline Sector: service & -0.001 & 0.01 \\
\hline Sector: other & -0.030 & 0.41 \\
\hline Managers & 0.190 & $2.83 * * *$ \\
\hline Clerks & 0.215 & $3.57 * * *$ \\
\hline Crafts \& Skilled workers & -0.027 & 0.33 \\
\hline Other occupations & 0.172 & $2.79 * * *$ \\
\hline \multicolumn{3}{|l|}{ Interaction terms } \\
\hline Wage differentials* Greece & 0.121 & 1.09 \\
\hline Wage differentials* France & 0.615 & $3.88 * * *$ \\
\hline Wage differentials* UK & 0.349 & $3.03 * * *$ \\
\hline Observations & \multicolumn{2}{|c|}{3,027} \\
\hline
\end{tabular}

Note $^{*}, * *, * * *$ indicate significance at $10 \%, 5 \%, 1 \%$ levels, respectively. 


\section{Is selectivity important?}

The results for the reduced form Probit can be used to control for sample selection when estimating wage equations for workers observed in dangerous and safe jobs. Table 2 columns 1 and 2 present the estimates for these wage equations (8). It is found that there is no effect of self-selection of workers into dangerous jobs and a positive selection of workers into safe jobs. There is evidence of positive selection into safe jobs since the significant negative coefficient on the inverse Mills ratio (selection term) implies that those less likely to work in dangerous jobs are those workers with high unobserved components of safe job wages. A more straightforward interpretation is that those choosing safe jobs have a comparative advantage or a preference for this kind of jobs. Thus, if workers in safe jobs moved to dangerous jobs they might be less satisfied as they put more weight on security than on wages, in which case the wage premium would not be enough to equalize their utility.

Table 2, column 3 presents the estimates of the treatment effect model (equation 10). One of the principal findings from the switching regression results of Table 2 (columns 1-2) still holds for the single-equation estimates, with a significant correlation between the errors in the wage and choice equations. Workers with positive unmeasured components of safe jobs earnings are less likely to work in dangerous jobs. While the single-equation results are consistent with the two-sector model, their validity is rejected by the F-test ${ }^{15}$.

\footnotetext{
15 The F-test for the equality of coefficients in the two groups is $F(20,3030)=5.42$ with $\operatorname{Pr}>F 0.000$ and is therefore significantly different from zero.
} 
Which is the effect of job risk in wage determination?

Table 2 (columns 1 and 2) reveals that the variables do not have the same influence in both wage equations. The two most important results is the positive effect of union status for workers in dangerous jobs and the non significant effect for workers in safe jobs. In the literature, it is usually stated that the presence of unions endows workers with some market power, a situation which is not considered in the pure theory of compensating differentials. An explanation usually put forward suggests that union workers may be better informed than non-union workers to have access to reliable information on risk and may be able to employ it more effectively when bargaining (Thaler and Rosen, 1975). Thus, some studies find that unionized workers obtain substantially higher compensations for fatal risk (Gerax et al, 1991). In addition, sociologists argue that workers are only compensated for bad working conditions when the bad quality of the job is publicly recognized (Baudelot and Gollac, 1993). Unions are therefore the only means for everyone to recognise whether a working condition is good or bad.

The remaining findings are consistent with the implications of the theoretical literature on wages, according to which males have higher wages than women in dangerous jobs. Returns to schooling are significant in both equations. Being married is significant in the wage equations for workers in dangerous jobs.

The two wage equations for workers in dangerous and safe jobs can be used to compute the wage differential for each person in the sample. The wage rate for workers in safe jobs is 9 percent higher than for workers in dangerous jobs. Suppose that we erroneously pool the data and do not correct for selectivity. The wage differential would then be biased downward by 6.2 percent. ${ }^{16}$ If instead we correct for selectivity but still erroneously pool the data (the

\footnotetext{
16 The wage OLS estimation is reported in Table 7 in the Appendix.
} 
Treatment Effect model, Table 2, column 3), the wage differential is also underestimated by 7.3 percent.

Are wages a utility equalizing device in the sense of the theory of compensating differentials?

The four countries examined in this study are very different in terms of labour demand and supply and institutional factors such as labour market centralization, union membership rates, etc. For instance, an issue that often raises debate on the validity of the theory of compensating differentials is its assumption of a perfectly competitive labour market. If the labour market is not perfectly competitive, the compensating wage differentials may be weak or even absent. The countries studied here have different labour market conditions. On one hand, in the UK the labour market is characterized by higher flexibility and employers must propose a higher risk premium, in order to attract workers, whereas in France and Greece the labour market is more centralized and wage determination is coordinated by institutional mechanisms in which the individualization of wages is not completely developed (Brizard, 2004).

Additionally, some studies find that compensating wage differentials are inversely correlated with unemployment. Thus, in countries where unemployment is relatively low and, consequently, job opportunities wider (like in our case, UK), workers earn a higher risk premium. Purse (2004) points out that workers confronted with a higher level of unemployment, especially those with a low level of education and few marketable skills, may be much less likely to quit their job, irrespective of whether or not it is hazardous. If this is the case in countries such as Greece and France, where the unemployment rate is higher compared to UK, the risk premium would be smaller or even absent. We address this issue 
by the use of appropriate interaction terms rather than estimating a different model for each country which would require a higher number of observations per country.

As mentioned above and according to the theory of compensating differentials, the wage differential that enters into satisfaction equations should be zero. Therefore, it would be expected that the coefficient of the wage differential estimated from these equations should not be significant. The econometric evidence from the risk-specific partial satisfaction regression (Table 3) shows that the wage differential yields lower satisfaction for Greek and British workers. This could probably mean that if dangerous jobs are also the low-paid ones, workers could be dissatisfied even if risk were compensated for, because even well-paid individuals would be paid less if they were in a dangerous job. In other words, risk is not fully compensated in the labour marker, thus reducing satisfaction. This result suggests that the market might possibly not clear, implying that workers who choose a dangerous job do so because they have no other alternative. In this line Purse (2004), who criticized the perfect mobility assumption, pointed out that "if workers do not have the freedom to change jobs when faced with unacceptable risks arising from their work, the presumed imperative placed on employers by the market to compensate them is correspondingly reduced. In the real world, workers are completely free to change jobs whenever they feel inclined to do so" (p.598). In the estimates reported in Table 3, it is also interesting to note that, in the second specification, the interaction term between wage differentials and trade union is not significant, whereas in the first specification, unionized workers are less satisfied with their job riskiness. This suggests that unionized workers' wages capture the corresponding workers' dissatisfaction. 
As a robustness test, we rerun the whole estimation using the measure of overall job satisfaction instead of satisfaction with job risk (see Table 4 ). It is found that higher wage differentials do yield extra satisfaction for French and British workers. This may be explained by the fact that wage is not the only argument in a worker's utility function. People could feel satisfied with their jobs even if they were not sufficiently compensated for working in a dangerous one. An explanation could be provided by using the multidimensional model of overall job satisfaction (Skalli et al, 2008). According to this model, overall utility of a job is the result of an aggregation of all sub-utilities related to a different mix of job characteristics (such as working conditions, security, type of work, wages etc.).

An individual could remain equally satisfied with his/her job if certain characteristics of the job changed, like for example, when working conditions deteriorate but this is accompanied by a permanent job contract in a way that the overall job satisfaction remains the same. Thus, two different mixes of characteristics for the same job may be viewed by the worker as equally attractive, provided that a low content in one desirable property is compensated by an increase in another.

In this way, a worker may be willing to accept voluntarily a risky job if he/she is compensated with more of another desirable attribute in a way that his/her satisfaction remains the same; e.g. a risky job which provides more security in terms of unemployment expectations, more convenient working time schedules and not particularly higher wages as wages present only one dimension of a job among others. 


\section{Conclusions}

This study tests the central implication of the theory of compensating differentials that workers are indifferent between risky and safe jobs in labour market equilibrium as long as wages serve as a utility equalizing device. Using satisfaction with job-related risk as a partial measure of overall job satisfaction we examine whether wage differentials act as a utility equalizing device counterbalancing job risk. We have used a selectivity corrected model in order to overcome biases present in previous related studies. It turns out that it is important to adjust for selectivity.

The econometric evidence shows that the wage premium for being in a dangerous job, is not sufficient to equalize workers' risk-related partial utility across job types. This could probably mean that dangerous jobs are also low-pay ones. Nevertheless, the wage differential yields higher overall job satisfaction and this probably says that workers are, in general, happy with their wages, although not sufficiently compensated for their job's riskiness. An explanation for this is that different job characteristics are substitutable, making a worker with low potential earnings in a safe job willing to accept a riskier job if he/she is sufficiently compensated with more of another desirable attribute. Thus, policies focusing on job characteristics reflected on overall job satisfaction would be as important as policies focusing on the level of pay. This, however, requires the design of a regulatory framework that promotes the transition of workers from one state (low pay/low quality) to another (high pay/high quality), by improving the dynamics that lead to jobs of superior quality and by encouraging occupational and regional mobility. And probably this is even more crucial in countries with a high level of employment protection, where as stated by Gielen and Tatsiramos (2011) it induces the employed worker to stay in a low satisfaction job until a better job is found. 
Policy makers should aim at designing specific measures which, apart from the objective risk of a job take into account the subjective perception of workers regarding their jobs' riskiness. Firms could also benefit from findings like those presented here to improve their workers' satisfaction using less costly strategies.

Future research could check the robustness of our results in a broader set of countries. It would also be necessary to extend the analysis to part time jobs which seem to constitute an especially interesting field for job risk management by regulators and firms. 


\section{References}

Arabsheibani, G. and Marin, A., 2000. Stability of Estimates for the Compensation of the Danger, Journal of Risk and Uncertainty, 20:247-269.

Arnould, R., and Nichols, L., 1983. Wage-Risk Premiums and Workers' Compensation: a Refinement of Estimates of Compensating Wage Differentials. Journal of Political Economy, 91:332-40.

Baudelot, C. and Gollac, M., 1993. Salaires et Conditions de Travail. Economie et Statistique, $265: 65-84$

Becker, G., 1964. Human Capital. The University of Chicago Press.

Bender, K. and Mridha, H. 2011. The effect of local area unemployment on compensating wage differentials for injury risk. Southern Economic Journal, 78:287-307.

Böckerman, P. and Ilmakunnas, P. 2006. Do Job Disamenities raise Wages or ruin Job Satisfaction? International Journal of Manpower, 27:290-302.

Böckerman, P., Ilmalunnas, P. and Johansson, E. 2011. Job security and employee wellbeing: Evidence form matched survey and register data. Labour Economics, 18:547-554.

Biddle, J.E. and Zarkin, G., 1988. Worker Preferences and Market Compensation for Job Risk. Review of Economics and Statistics, 70: 660-67. 
Brown, C., 1980. Equalizing Differences in the Labour Market. Quarterly Journal of Economics, 94:113-34

Brown, C., and Medoff, J., 1989. The Employer Size-wage Effect. Journal of Political Economy, 97, 1027-1059.

Brizard, A., 2004. 1999-2002: des Hausses de Salaires de moins en moins Individualisées. Premières Informations, Premières Synthèses, DARES, ${ }^{\circ} 22.1$

Cahuc, P. and Zajdela, H., 1991. Comment expliquer le dualisme du marché du travail à partir de comportements rationnels ? Revue Economique, 3:469-491.

Clark, A., 2003. Looking for Labour Market Rents with Subjective data. DELTA, mimeo.

Clark, A. and Postel-Vinay, F. 2009. Job security and job protection. Oxfort Economics Papers, 61:207-239.

Coles, M., Lanfranchi, J., Skalli, A., and Treble, J., 2007. Pay, Technology, and The Cost of Worker Absence. Economic Inquiry, 45:268-285.

Dale-Olsen, H., 2006. Estimating Worker' Marginal Willingness to Pay for Safety Using Linked Employer-Employee Data. Economica, 73:99-127. 
Daniel, C. and Sofer, C., 1998. Bargaining, Compensating Wage Differentials, and the Dualism of the Labor Market: Theory and Evidence for France. Journal of Labor Economics, $16: 546-575$.

DeLeire, T. and Levy, H., 2004. Worker Sorting and the Risk of Death on the Job. Journal of Labor Economics, 22: 925-953.

Doeringer, P. and Piore, M., 1971. Internal Labor Markets and Manpower Analysis. Massachusetts.

Dohmen, T., Falk, A., Huffman, D., Sunde U., Schupp, J. and Wagner, G., 2005, Individual Risk Attitudes: New Evidence from a Large, Representative, Experimentally-Validated Survey. IZA Discussion Paper No. 1730

Dorman, P., 1996. Markets and Mortality: Economics, Dangerous Work and the Value of Human Life. Cambridge: Cambridge U. Press.

Dorman, P., and Hagstrom, P., 1998. Wage Compensation for Dangerous Work Revisited. Industrial and Labour Relations Review, 52:116-35.

Dickens, W., 1985. Occupational Safety and Health Regulation and Irrational Behavior: A Preliminary Analysis, in John D. Worrall and David Appel, eds., Workers' Compensation Benefits: Adequacy, Equity and Efficiency, ILR Press, pp. 19-40. 
Dickens, W. and Katz, L., 1987. Where Have All the Good Jobs Gone?: Deindustrialization and Theories of Dual Labour Markets," in Lang, K. and Leonard, J., eds. Unemployment and the Structure of Labour Markets, New York: Basil Blackwell, 1987.

Duncan, G. and Holmlund, B., 1983. Was Adam Smith Right After all? Another test of the Theory of Compensating Wage Differentials. Journal of Labour Economics, 1:367-79.

Fairris, D., 1989. Compensating Wage Differentials in the Union and Nonunion Sectors, Industrial Relations 28: 356-372.

Freeman, R.B., 1978. Job Satisfaction as an Economic Variable. American Economic Review, 68:135-141.

French, T. and Dunlap, J., 1998. Compensating Wage Differentials for Job Stress. Applied Economics, 30:1067-1075.

Garen, J. 1988. Compensating Wage Differentials and the Endogeneity of Job Riskiness. The Review of Economics and Statistics, 70:9-16.

Gariety, B. and Shaffer, S., 2001. Wage Differentials Associated with Flexitime. Monthly Labor Review, 124:68-75.

Gegax, D., \& Gerking, S. and Schulze, W., 1991. Perceived Risk and the Marginal Value of Safety. Review of Economics and Statistics, 73:589-96. 
Gielen, A.,\& Tatsiramos, K., 2011. Quit Behavior and the Role of Job Protection, Working paper.

Godechot, O. and Gurgant, M., 2000. Quand les salariés jugent leur salaire, Economie et Statistique, 331: 3-24.

Gronberg, T. and Reed, W., 1994. Estimating workers' marginal willingness to pay for job attributes using duration data, Journal of Human Resources, 24: 911-931.

Hamermesh, D.S. (1978). Economic Aspects of Job Satisfaction. In O. Ashenfelter and W. Oates (eds.), Essays in Labour Market Analysis. New York: John Wiley and Sons, pp.53-72.

Helliwell, J.F. and Huang, H. 2010. How's the job? Well-being and social capital in the workplace. Industrial and Labor Relations Review, 63:205-227.

Hwang, H., Reed, R. and Hubbard, C., 1992. Compensating Wage Differentials and Unobserved Productivity. Journal of Political Economy, 100:835-58.

Kahneman, D. and Tversky, A., 1979. Prospect Theory: An Analysis of Decisions Under Risk. Econometrica, 47: 263-291.

Kostiuk, P.F., 1990. Compensating Differentials for Shift Work. Journal of Political Economy, 98:1055-75. 
Krueger, A. and Summer, L., 1988. Efficiency Wages and the Inter-industry Wage Structure. Econometrica, 56: 259 - 293.

Kruse, D., 1992. Supervision, Working Conditions and the Employer size-Wage Effect, Industrial Relations, 31:229-49.

Lalive, R., 2007. Do Wages Compensate for Workplace Amenities? Applied Economics Quarterly, 53:273-298.

Lalive, R., Ruf, O. and Zweimuller, J., 2006. Wages and Risks at the Workplace: Evidence from Linked Firm-Worker Data. mimeo. University of Zurich

Lanfranchi, J., Ohlsson, H., and Skalli, A., 2002. Compensating Wage Differentials and Shift Work Preferences. Economics Letters. 74:393-98.

Lee, L., 1978.Unionism and Wage Rates: A Simultaneous Equations Model with Qualitative and Limited Dependent Variables. International Economic Review, 19:415-33.

Lichtenstein, S. and Slovic, P., 1971. Reversals of Preference Between Bids and Choices in Gambling Situations. Journal of Experimental Psychology, 89: 46-55.

Maddala, G., 1983. Limited Dependent and Qualitative variables in Econometrics. Cambridge University Press, Cambridge. 
Magnani, E., 2002. Product Market Volatility and the Adjustment of Earnings to Risk. Industrial Relations 41: 304-328.

Marin, A. and Psacharopoulos, G., 1982. The Reward of Risk in the Labor Market: Evidence from the United Kingdom and Reconciliation with other Studies. Journal of Political Economy, 90:827-53.

Martinello, F., and Meng, R., 1992. Work-place Risks and the Value of Hazard Avoidance. Canadian Journal of Economics, 25:333-45.Meng, R., and Smith, D., 1990. The Valuation of Risk Death in Public Sector Decision-Making. Canadian Public Policy, 16: 137-44.

Moretti, E., 2000. Do Wages Compensate for Risk of Unemployment? Parametric and Semiparametric Evidence from Seasonal Jobs. Journal of Risk and Uncertainty 20: 45-66.

Mincer, J., 1958. Investment in Human Capital and the Personal Income Distribution. Journal of Political Economy, 66:281-302.

Nielsen, A. 2005. Gender Wage Gap Is Feminist Fiction? Available online at http://www.iwf.org/articles/article_detail.asp?ArticleID=749 .

Purse, K., 2004. Work-Related Fatality Risks and Neoclassical Compensating Wage Differentials. Cambridge Journal of Economics, 28:597-617.

Rosen, S. 1986. The Theory of Equalizing Differences. In O. Ashenfelter and P.R.G., Layard (eds), Handbook of Labor Economics, Vol 1. North-Holland, Amsterdam, pp. 641-92. 
Sandy, R. and Elliott, R., 1996. Unions and Risk: Their Impact on the Compensation for Fatal Risk. Economica, 63:291-309.

Sloane, P. and Grazier, S., 2006. Accident Risk, Gender, Family Status and Occupational Choice in the UK. IZA Discussion Paper No. 2302.

Skalli, A, Theodossiou, I, and Vasileiou, E. 2008. Jobs as Lancaster Goods: Facets of Job Satisfaction and Overall Job Satisfaction. Journal of Socio-Economics, 37:1906-1920.

Smith, A., 1776[1991]. Recherches sur la nature et les causes de la richesse des Nations, Flammarion, GF.

Staiger, D. and Stock, J.H., 1997. Instrumental Variables Regression with Weak Instruments. Econometrica, 65:363-376.

Starr, C., 1969. Social Benefits vs Technological Risk. Science, 19:1232-38.

Stutzer, A. and Frey, B. 2008. Stress that doesn’t pay: The commuting paradox. Scandinavian Journal of Economics, 110:339-366.

Thaler, R. and Rosen, S., 1975. The Value of Saving a Life: Evidence from the Labour Market in N. Terleckyj (ed.) Household Production and Consumption (Columbia U.P.)

Viscusi, W.K, 1979. Employment hazards: An Investigation of Market Performance. Cambridge: Harvard U. Press. 
Viscusi, W.K, 1978. Wealth Effects and Earnings Premiums for Job Hazards. The Review of Economics and Statistics, 60:408-19.

Viscusi, W.K. and O'Connor, C., 1984. Adaptive Responses to Chemical Labeling: Are Workers Bayesian Decision Makers?. American Economic Review, 74:942-56.

Viscusi, W.K.,1993. The Value of Risks to Life and Health. Journal of Economic Literature, 31:1912-1946.

Viscusi, W. K. and Aldy, J. E., 2003. The Value of a Statistical Life: A Critical Review of Market Estimates Throughout the World. Journal of Risk and Uncertainty, 27: 5-76.

Wei, X. 1999. Estimating British workers' demand for safety. Applied Economics, 31: 12651271. 


\section{Appendix}

Table 5

Sample descriptive statistics

\begin{tabular}{|c|c|c|}
\hline Variables & Safe Jobs & $\begin{array}{l}\text { Dangerous } \\
\text { jobs }\end{array}$ \\
\hline & \multicolumn{2}{|c|}{ Mean(SD) } \\
\hline $\begin{array}{l}\text { Satisfaction with the job related } \\
\text { risk ( } 1 \text { to } 10)\end{array}$ & $7.3(2.6)$ & $5.07(2.8)$ \\
\hline Overall Job Satisfaction (1 to 10 ) & $6.8(2.01)$ & $6.5(2.1)$ \\
\hline Net hourly wage (euros) & $7.8(4.8)$ & $6.7(5.1)$ \\
\hline Household member's income & 0.65 & 0.59 \\
\hline Male (dummy) & 0.40 & 0.67 \\
\hline Married (dummy) & 0.67 & 0.71 \\
\hline Tenure (years in firm) & $8.1(8.8)$ & $8.7(8.5)$ \\
\hline Primary education (dummy) & 0.19 & 0.31 \\
\hline Secondary education (dummy) & 0.41 & 0.41 \\
\hline $\begin{array}{l}\text { Upper secondary education } \\
\text { (dummy) }\end{array}$ & 0.39 & 0.28 \\
\hline Member of Union (dummy) & 0.17 & 0.29 \\
\hline Managers_Prof (dummy) & 0.15 & 0.18 \\
\hline Clerk (dummy) & 0.38 & 0.12 \\
\hline $\begin{array}{l}\text { Craft and Skilled workers } \\
\text { (dummy) }\end{array}$ & 0.06 & 0.24 \\
\hline Sales (dummy) & 0.18 & 0.15 \\
\hline Other_Occupat (dummy) & 0.23 & 0.31 \\
\hline $\begin{array}{l}\text { Past Unemployment experience } \\
\text { (dummy) }\end{array}$ & 0.09 & 0.10 \\
\hline Industrial sector (dummy) & 0.10 & 0.22 \\
\hline Service sector (dummy) & 0.75 & 0.64 \\
\hline Other_sector (dummy) & 0.15 & 0.14 \\
\hline Private (dummy) & 0.69 & 0.67 \\
\hline France (dummy) & 0.25 & 0.28 \\
\hline The Netherlands (dummy) & 0.29 & 0.17 \\
\hline Greece (dummy) & 0.14 & 0.33 \\
\hline The UK (dummy) & 0.32 & 0.22 \\
\hline Observations & 1,934 & 1,096 \\
\hline
\end{tabular}


Table 6

Variable List

\section{Variables}

Satisfaction with Physical

risk (1 to 10)

Overall Job Satisfaction

Dangerous jobs

Net hourly wage

Age (years)

Male

Married

Tenure (years in firm)

Low education

Secondary education

Upper secondary education

Member of Union

Managers_Professional

Clerks

Craft and Skilled workers

Sales

Other_Occupations

Past Unemployment

experience

Working in private sector

Industrial sector

Service sector

\section{Definition}

Standardized score of an individual' s satisfaction with risk, which is measured on an eleven point scale of $0=$ not at all satisfied to

$10=$ very satisfied

Standardized score of an individual' s overall job satisfaction, which is measured on an eleven point scale of $0=$ not at all satisfied

to $10=$ very satisfied

Dummy variable equal to 1 if the individual replies that his/her job is dangerous frequently or sometimes and 0 otherwise

Log of CPI-deflated hourly wage in euros

Age of the respondent in years (18 to 65)

Dummy variable equal to 1 if the respondent is a man

Dummy variable equal to 1 if the respondent is married or cohabits

Number of years of the respondent with current employer

Dummy variable - Less than second stage of secondary level education

Dummy variable- Second stage of secondary level education

Dummy variable - Post-secondary level education

Dummy variable equal to 1 if the respondent is in a trade union

Dummy variable- Managers \& Professionals and associate professional

Dummy variable - Clerks and service occupations

Dummy variable- Craft, related trades workers, plant, machine operators and assemblers

Dummy variable- Service and Sales workers

Dummy variable-Armed forces-other occupations

Dummy variable equal to 1 if the respondent has weeks of unemployment during the last year and 0 otherwise

Dummy variable equal to 1 if the respondent works in the private sector

Dummy with value 1 for workers in the agricultural sector, manufacturing and electricity, mining and gas and water supply sector

Dummy with value 1 for workers in the service sector; wholesale, hotels, transport, financial intermediation, real estate, education health and social work 


\begin{tabular}{|l|l|}
\hline Other_sector & Dummy with value 1 for workers in the sector of other activities \\
\hline Firmsize_24 & Dummy variable equal to 1 if the respondent works in a firm with number of employees :1 to 24 people \\
\hline Firm size_99 & Dummy variable equal to 1 if the respondent works in a firm with number of employees: 25 to 99 people \\
\hline Firm size more than 100 & Dummy variable equal to 1 if the respondent works in a firm with number of employees: more than 100 people \\
\hline Countries & Dummy variables for the following countries: France, Great Britain, Greece, and the Netherlands. \\
\hline $\begin{array}{l}\text { Household member's } \\
\text { income }\end{array}$ & $\begin{array}{l}\text { Dummy variable with value } 1 \text { if the respondent has a member in the family who provides the household with extra income } \\
\text { and 0 otherwise }\end{array}$ \\
\hline
\end{tabular}


Table 7:Wage equation, OLS Estimation

\begin{tabular}{|c|c|c|}
\hline Variables & Coef. & $t$-stat \\
\hline Dangerous job & -0.062 & $3.22 * * *$ \\
\hline Married & 0.054 & $3.14 * * *$ \\
\hline Male & 0.131 & $7.80 * * *$ \\
\hline Tenure & 0.020 & $6.34 * * *$ \\
\hline Tenure $^{2} / 100$ & -0.038 & $3.71 * * *$ \\
\hline Secondary education & 0.061 & $2.81 * * *$ \\
\hline Upper secondary education & 0.113 & $5.00 * * *$ \\
\hline Trade Union $\mathrm{Mb}$ & 0.039 & $2.08 *$ \\
\hline Manager & 0.229 & $8.66^{* * *}$ \\
\hline Clerk & 0.128 & $5.35 * * *$ \\
\hline Craft_skilled & 0.039 & 0.40 \\
\hline Other occupant. & 0.090 & $3.63 * * *$ \\
\hline Private & -0.048 & $2.72 * *$ \\
\hline Unemployment Experience & -0.062 & $2.19 * *$ \\
\hline Firm size $<99$ & 0.015 & 0.75 \\
\hline Firm size $>100$ & 0.044 & $2.14 * *$ \\
\hline Service_sector & -0.053 & $1.94^{*}$ \\
\hline Other sector & -0.047 & 1.57 \\
\hline Greece & -0.955 & $43.40 * * *$ \\
\hline France & -0.172 & $8.50 * * *$ \\
\hline UK & -0.430 & $16.26 * * *$ \\
\hline Constant & 1.912 & $35.53 * * *$ \\
\hline Observations & \multicolumn{2}{|c|}{3,030} \\
\hline Adjusted $\mathrm{R}^{2}$ & \multicolumn{2}{|c|}{0.49} \\
\hline
\end{tabular}

